\title{
Accounting and Analysis of Biological Asset Transformation Results in Agricultural Companies of the Russian Federation
}

\author{
Stanislava KONTSEVAYA ${ }^{1, *}$, Rolan ALBOROV ${ }^{2}$, Svetlana KONTSEVAYA ${ }^{2}$, Lubos SMUTKA ${ }^{3}$, \\ Irina MAKUNINA ${ }^{1}$ and Bazhan TUREBEKOVA ${ }^{4}$ \\ 1 Russian State Agrarian University - Moscow Timiryazev Agricultural Academy, Moscow, Russia; \\ s.konsevaya@mail.ru; i.makunina@mail.ru \\ 2 Izhevsk State Agricultural Academy, Izhevsk, Russia; sv.koncevaya@ mail.ru; r.alborov@ mail.ru \\ 3 Czech University of Life Sciences, Prague, Czech Republic; smutka@pef.czu.cz \\ 4 Kazakh University of Technology and Business, Nursultan, Kazakhstan; b.turebekova@gmail.com \\ * Correspondence: s.konsevaya@mail.ru
}

\begin{abstract}
According to IAS 41 "Agriculture" an agricultural company should keep accounting of agricultural products represented by fair value net of sale costs unconditionally. Bio assets should be evaluated by fair value net of sale costs until they are transformed into agricultural products. This article is aimed to suggest a new procedure on analyzing financial results of an agricultural company with regard to bio assets. The suggested procedure can be implemented in the companies splitting accounting of costs into variable and fixed ones and in the companies practicing conventional cost accounting procedures. Integrated agricultural production company "Kolos" was the base for the following research. Recommended procedure of control and analysis of presented indexes evaluates the extent of influence of managerial decision about allocation and utilization of bio assets on return on production investments, output of agricultural products obtained from bio assets. The output is assessed by gross product evaluated by fair value net of sale costs, gross margin, gross profit, labor productivity in plant breeding, animal breeding and in general agricultural activity.
\end{abstract}

Keywords: agricultural products; fair value; operational profit margin; gross profit margin; cost

JEL Classification: M11; M41; Q12

\section{Introduction}

Agricultural activity is a complex system of continuous reproduction of streamlined processes of plant breeding and animal breeding. This system also comprises management of plants and animals' biotransformation (bio assets) for manufacturing agricultural products and its sale or utilization for manufacturing additional bio assets.

Bio assets should be evaluated by fair value net of sale costs until they are transformed into agricultural products excluding those cases when fair value can't be defined reliably in initial recognition.

Bio assets have the key role in the agricultural companies. Hie et.al. (2019) noted that accounting of biological assets has significant positive effect on cost of debt capital.

An agricultural company should keep accounting of agricultural products represented by fair value net of sale costs unconditionally. Fair value of harvested agricultural products net of sale costs and change of fair value of bio assets is to be taken into account in calculation of actual financial results of plant and animal biotransformation for the specific accounting period (Alborov 2012). Da Rocha et.al. (2016) in the research suggests the procedure of bio asset accounting which uses an accounting information about groups of assets and combined assets.

As a process of bio asset management, agricultural activity is usually subdivided into the following branches of production corn and grain legume, industrial crops, potato farming, vegetable 
farming, fruit farming, vine growing, fodder production, cattle breeding, swine keeping, sheep breeding and goat breeding, poultry breeding, horse breeding, beekeeping, fur breeding, fish farming, rabbit breeding, etc.

Accounting objects in agricultural activity of economic entities are the following bio assets and the products, resulting from biotransformation of these assets, corn and grain legume, industrial crops, vegetables and potato, fruits, admitted as bio assets by a company, fodder crops and others, meat and milk cattle including those which are raised and fattened, pigs and breeding pigs of all ages and piggery, sheep, goats, lambs and goatlings, mature poultry stock and growing birds, reproductive herd of all ages and yield of rabbits and fur animals and other bio assets.

Besides accounting objects might be all kinds of agricultural products cropped or obtained from plant breeding (including fruit crops which were not admitted as bio assets by a company) and animal breeding bio assets, costs of some agricultural activities (wages, social security contributions, material costs, bio costs, depreciation costs, other costs in plant and animal breeding), fair value of bio assets net of sale costs (fair value is calculated at the moment of asset declaration), changes of fair value at the regular accounting date, government subsidies related to the certain asset, which is presented in fair value net of sale costs, free of conditions in that period when it was provided, and financial results of agricultural activity (incomes, expenditures, profits and losses).

Modification of physical characteristics of assets or changes in market prices might cause changes in fair value of bio assets net of sale costs. Calculation of deviations and disclosure of the information about changes caused by physical characteristics (quantity/number) of bio assets and price alteration helps evaluating results of activity for the current period and future prospects especially in case of biotransformation exceeding 1 year. Hence, evaluation and analysis should be done for definite kinds and groups of bio assets with regard to value of recognized financial results (incomes and expenses) from variation of fair value net of sale costs caused by changed physical properties and prices. This information might be also used for bio assets control and efficient utilization (Ostaev 2019).

Biotransformation causes such physical changes as growth, degeneration, production and reproduction and each of them can be observed and evaluated. Each of these changes concerns future economic profits directly. Variation of fair value of bio assets inspired by crop harvesting is also change of physical characteristics viz. quantity. (Kontsevoy 2015). The accounting of bio assets is regulated by the International accounting standard 41 "Agriculture", however, there are some specificities which are not taken into account in the standard. The example of such specificity is a problem in accounting recognition in costs of biological assets which allow the plant to be available for using, but occur when the asset is already in production (Marcolini et. al. 2015). Mikuska et.al.(2017) confirmed that the measurement of biological assets, by fair value methodology, significantly changes the book value of equity, directly influencing the profit or loss of the entity.

This article is aimed to suggest new procedure on analyzing financial results of an agricultural company with regard to bio assets.

\section{Methodology}

Developing accounting policy, an agricultural company may choose one of three recommended ways of accounting (by fair value) and utilization of accounting information about bio assets and their transformation (including agricultural products):

1. To generate a report on financial results of agricultural activity only;

2. To generate a balance sheet report and report on financial results of agricultural activity;

3. To manage bio resources of a company.

Then annual and interim accounting reports are generated with regard to chosen way of accounting policy in so far as accounting of bio assets and results of their transformation estimated by fair value net of sale costs. 
Incomes, expenditures, profit and losses of agricultural activity should be fixed in accounting records when establishing accounting of bio assets and agricultural products by fair value net of sale costs.

Incomes and expenditures, initially generated when admitting bio assets by fair value net of sale costs and changing fair value, are recommended to put into accountings with regard to duration of biotransformation as a part of:

1. Expected (potential) incomes and expenditures over the period when they are generated from bio assets with biotransformation duration more than 1 year;

2. Actual incomes and expenditures over the current period obtained from bio assets with limited biotransformation duration (not more than 1 year).

Incomes and expenditures, generated during initial admitting of agricultural final products (obtained after harvesting) by fair value net of sale costs, are included into actual incomes or expenditures over the accounting period during which they are generated.

Incomes and expenditures, generated during initial admitting of agricultural non-market products (fodders, seeds, organic fertilizers, secondary production of fruit farming) by fair value net of sales, may comprise both expected (potential) incomes and expenditures over the period or actual incomes and expenditures over the period during which they are generated. Company's accounting policy contains one of these two ways of admitting incomes and expenditures. If the first way is implemented, expected (potential) incomes and expenditures should be included into actual incomes and expenditures of the current period with charge off of presented non-market products (fodders, seeds, organic fertilizers, secondary production of fruit farming) in costs of plant and animal breeding.

Government subsidies, related to bio assets estimated by fair value net of sale costs free of conditions, should also be admitted and taken into account as expected (potential) incomes or actual incomes over the current period (depending on biotransformation duration of bio assets to which these subsidies are related), if these subsidies are surely be obtained.

Incomes and expenditures of agricultural activity can be taken into account in the following deposits ("Sales", "Other incomes and expenditures", "Expected (potential) incomes and expenditures") in correspondence with deposits on accounting of consequent bio assets and agricultural products estimated by fair value net of sale costs.

An agricultural company utilizes deposits in accordance with its accounting policy where working plan of deposits is approved.

Profits and losses, taking place during initial admitting of bio assets by fair value net of sale costs or changing of fair value, are taken into account as a part of profits and losses over the period during which they are generated. Profits and losses, taking place during initial admitting of agricultural products by fair value net of sale costs, are taken into account as a part of profits and losses over the period during which they are generated (at the deposit "Profits and losses").

In whole total profit and total loss brought by agricultural activity of a company (biotransformation of bio assets) are defined by comparison of total profit and total loss of agricultural activity.

The analysis is based upon accounting records and internal accounting documents of the integrated agricultural production company "Kolos" for 2018. Examples of calculations were made in accordance with the suggested procedure and on the basis of the accounting records of the integrated agricultural production company "Kolos" in order to evaluate profit of the agricultural company.

Agricultural companies are recommended to control and analyze efficiency indexes of bio asset utilization and production indexes of agricultural products obtained from these assets in order to make managerial decision concerning efficiency of bio asset utilization for sustainable development of the agricultural activity. These indexes are gross margin, operational profit and profit margin from asset biotransformation. Recommended equation for calculation of total gross profit of the agricultural company from asset biotransformation (Gross profit bio) is the following: 
where Fair value - Fair value of the whole harvested (obtained) agricultural products (plant breeding and animal breeding products) net of sale costs for accounting period, thou. RUB:

Change - alteration (increase or decrease) of fair value of bio assets net of sale costs as of the end of the accounting period, thou. RUB.;

$\sum$ Direct bio cost - an amount of direct (main process) costs for agricultural production and growing bio assets of plant breeding and animal breeding in the specific accounting period, thou. RUB.;

At the same time operational profit bio (operational loss bio) of the whole agricultural activity (from asset biotransformation) is recommended to calculate by the following equation:

$$
\text { Operational profit bio }=\text { Gross margin bio }-\sum \text { Cost }
$$

Where $\sum$ Cost - the amount of direct general and administrative expenses assigned to plant breeding and animal breeding as of the ending date of the specific accounting period, thou. RUB.

Profit margin from asset biotransformation (Profit margin bio) for the whole of the company is recommended to calculate by the following equation:

$$
\text { Profit margin bio }=\frac{\text { Operational profit bio }}{\sum \text { Direct bio cost }+\sum \operatorname{Cost}} \times 100
$$

Such indexes as gross margin and operational profit are recommended to calculate and analyze per unit of bio assets, for instance, per 1 ha of plants and per 1 head/beast.

These indexes can be analyzed in dynamics or compared with planned amounts.

If the company is unable to calculate gross margin and operational profit from the production of agricultural products for the reason of non-use (absence) of subdivision of production expanses of plant breeding and animal breeding into direct and fixed ones in the accounting system of the company, instead the company is recommended to control and analyze gross profit and operational profit of plant breeding and animal breeding separately.

So gross profit from the agricultural production can be calculated by the equation

- for plant breeding:

$$
\text { Gross profit bio } P=\text { Fair value } P-\text { Material cost } P-\text { Depreciation } P-\text { Other costs } P
$$

- for animal breeding:

$$
\text { Gross profit bio } A=\text { Fair value } A-\text { Material cost } A-\text { Depreciation } A-\text { Other costs } A
$$

where Gross profit bio P and Gross profit bio A - gross profit from plant breeding and animal breeding consequently, thou. RUB.;

Fair value $\mathrm{P}$ and Fair value $\mathrm{A}$ - gross product of plant breeding and animal breeding consequently, evaluated in fair value net of sale costs;

Material cost $\mathrm{P}$ and Material cost $\mathrm{A}$ - material costs of plant breeding and animal breeding consequently, thou. RUB;

Depreciation P, Depreciation A and Other costs P, Other costs A - depreciation and other costs in plant breeding and animal breeding consequently, thou. RUB.

In this case operation profit from agricultural production is calculated by the equation:

- for plant breeding:

$$
\text { Operation profit bio } P=\text { Gross profit bio } P-\text { Salary cost } P
$$

- for animal breeding:

$$
\text { Operation profit bio } A=\text { Gross profit bio } A-\text { Salary cost } A
$$

where Operation profit $\mathrm{P}$ and Operation profit $\mathrm{A}$ - operation profit in plant breeding and animal breeding consequently, thousands. RUB; 
Salary cost P and Salary cost A - salary costs including social payments in plant breeding and animal breeding consequently, thousands. RUB;

Abovementioned indexes for specific agricultural plants (groups of plants) and animals (groups of animals) should be calculated in accordance with the data from specific accounting records of the agricultural companies.

\section{Results}

The company is recommended to refer to the chain substitution method (Table 1) in the explanatory note to the accounting (financial) statements in order to evaluate, analyze and disclose the information about changes of fair value net of sale costs.

Table 1. Main indexes of bio asset fair value of the integrated agricultural production company

"Kolos" for 2018, thousands RUB.

\begin{tabular}{lrrrrrrr}
\hline $\begin{array}{c}\text { Types and groups of bio } \\
\text { assets }\end{array}$ & Unit & \multicolumn{2}{c}{ Quantity } & \multicolumn{2}{c}{$\begin{array}{c}\text { Fair value per unit, } \\
\text { thou. RUB }\end{array}$} & \multicolumn{2}{c}{$\begin{array}{c}\text { Total fair value, thou. } \\
\text { RUB }\end{array}$} \\
& & $\mathbf{2 0 1 7}$ & $\mathbf{2 0 1 8}$ & $\mathbf{2 0 1 7}$ & $\mathbf{2 0 1 8}$ & $\mathbf{2 0 1 7}$ & $\mathbf{2 0 1 8}$ \\
\hline \multicolumn{1}{c}{1} & 2 & 3 & 4 & 5 & 6 & 7 & 8 \\
A herd of milk cows & head & 840 & 860 & 34.54 & 39.19 & 29,012 & 33,693 \\
Fatteners (Cattle) & head & 518 & 509 & 16.46 & 15.33 & 8,526 & 7,805 \\
Rearers (heifers) & head & 212 & 163 & 45.38 & 50.73 & 9,621 & 8,269 \\
TOTAL & $X$ & $X$ & $X$ & $X$ & $X$ & 47,159 & 49,767 \\
\hline
\end{tabular}

Fair value net of sale costs of bio assets has grown on 2,608 thousand. RUB by the end of the accounting period according to the Table 1 and the Table 2 . This amount is obtained by variation of fair value net of sale costs due to growth of this value per 1 unit of assets and decrease of quantity of bio assets in the company.

Table 2. Evaluation and analysis of fair value variation of the integrated agricultural production company "Kolos" for 2018, thousands RUB.

\begin{tabular}{|c|c|c|c|c|}
\hline \multirow{4}{*}{$\begin{array}{c}\text { Types and } \\
\text { groups of bio } \\
\text { assets }\end{array}$} & \multirow{3}{*}{$\begin{array}{l}\text { With regard to } \\
\text { fair value per unit } \\
\text { in } 2017 \text { and the } \\
\text { quantity of the } \\
\text { assets in } 2018, \\
\text { thou. RUB }\end{array}$} & \multicolumn{3}{|c|}{ Fair value variation $(+,-)$, thousands RUB } \\
\hline & & \multicolumn{3}{|c|}{ Including deviations of } \\
\hline & & Total & Fair value per unit & $\begin{array}{c}\text { Quantity of bio } \\
\text { assets }\end{array}$ \\
\hline & $\begin{array}{c}9=\text { column } 4 \times \\
\text { column } 5\end{array}$ & $\begin{array}{c}10=\text { column } 8 \\
- \text { column } 7\end{array}$ & $\begin{array}{c}11=\text { column } 8- \\
\text { column } 9\end{array}$ & $\begin{array}{c}12 \text { = column } 9 \\
- \text { column } 7\end{array}$ \\
\hline \multicolumn{5}{|l|}{ A herd of milk } \\
\hline cows & 29,703 & $+4,681$ & $+3,990$ & +691 \\
\hline Fatteners (Cattle) & 8,378 & -721 & -573 & -148 \\
\hline Rearers (heifers) & 7,397 & $-1,352$ & +872 & $-2,224$ \\
\hline TOTAL & 45,478 & $+2,608$ & $+4,289$ & $-1,681$ \\
\hline
\end{tabular}

The following changes of fair value net of sale costs occurred by types and groups of bio assets separately: a herd of milk cows - increase of fair value on 4,681 thousand RUB including one happened due to both deviation of fair value per one cow and deviation of the number of cows in the herd by the end of the accounting period; fatteners (cattle) - decrease of fair value on 721 thousand RUB including one happened due to both deviation of fair value per 1 head/beast of fatteners and decrease of the number of fatteners; rearers (heifers) - decrease of fair value on 1,352 thousand RUB including increase of fair value per 1 head/beast of rearers (heifers) and decrease of fair value because of reduced number of heifers by the end of the accounting period. 
Evaluation and accounting of bio assets and agricultural products by fair value is incomplete without settlement of control and analytical aspects of the agricultural activity control.

The calculation of profitability indexes using formulae 1, 2, 3 based on the information from the integrated agricultural production company "Kolos" for 2018 is presented below. Fair value of total harvested products was 8,320 thousand RUB, change (increase) of fair value for the accounting period was 2,608 thousand RUB, $\sum$ Direct bio cost for agricultural production and growing of bio assets of plant breeding and animal breeding was 6,536 thousand RUB, $\sum$ Cost as of the end of the accounting period was 1,758 thousand RUB. The following indexes are calculated according to the abovementioned values:

- Gross profit from biotransformation of assets:

Gross profit bio $=8,320+2,608-6,536=4,392$ thousand RUB;

- Operation profit from biotransformation of assets:

Operation profit bio $=4,392-1,758=2,634$ thousand RUB;

- Profit margin from biotransformation of assets:

Profit margin bio $=2,634:(6,536+1,758) \times 100=31,75 \%$.

An example of calculation of profitability indexes of plant breeding and animal breeding without subdivision of costs into direct and fixed ones using formula 4, 5, 6, 7 is presented below.

Gross product of plant breeding evaluated by fair value (Fair value P) - 3,523 thousand RUB, Gross product of animal breeding evaluated by fair value (Fair value A) - 4,506 thousand RUB, material costs in plant breeding (Material cost P) - 2,287 thousand RUB, material costs in animal breeding (Material cost A) - 3,049 thousand RUB, depreciation in plant breeding (Depreciation P) 225 thousand RUB, depreciation in animal breeding (Depreciation A) - 295 thousand RUB, other costs in plant breeding (Other costs P) - 104 thousand RUB, other costs in animal breeding (Other costs A) 115 thousand RUB, salary costs including social payments in plant breeding (Salary cost P) - 803 thousand RUB, salary costs including social payments in animal breeding (Salary cost A) - 958 thousand RUB. The following indexes are calculated according to the abovementioned values:

- Gross profit for animal breeding and plant breeding:

Gross profit bio $P=3,523-2,287-225-104=907$ thousand RUB;

Gross profit bio $A=4,506-3,049-295-115=1,047$ thousand RUB;

- Operation profit for animal breeding and plant breeding:

Operation profit bio $P=907-803=104$ thousand RUB;

Operation profit bio $A=1,047-958=89$ thousand RUB.

Recommended procedure of control and analysis of presented indexes provides a possibility to evaluate the extent of influence of managerial decision concerning allocation and utilization of bio assets on returns on production costs, obtained results harvested from bio assets of agricultural products, gross product evaluated in fair value, gross margin, operation profit, labor productivity in plant breeding, animal breeding and agricultural activity in general.

Resting upon this control and analysis controllers and managers of companies are able to make managerial decisions concerning regulating and correcting plans, development strategies, structure and content of bio assets, bio asset production costs and optimization of volumes of products harvested from bio assets.

This procedure was developed as an integral part of the guidelines of Ministry of Agriculture of the Russian Federation.

\section{Discussion}

Presented procedure is quite simple and can be implemented in relatively small agricultural companies. However, evaluation of fair value is a question for discussion. In some cases, fair value can't be defined with appropriate degree of reliability. However, the survey presented in the research of Hinke and Stárová (2014) proved that farmers in the Czech Republic are rather restrained as for the use of value measurement of biological assets and agricultural production. 
Further researches will be devoted to study of the accounting records of agricultural companies for some years. These companies implemented new procedure. So future research will be devoted to comparison of the periods when the companies utilized conventional accounting procedure and the periods after implementation of the suggested procedure.

\section{Conclusion}

Estimation by fair value helps take correct managerial decisions. Suggested methodology provides two ways of the analysis of financial results and includes procedure for those companies which carry out traditional accounting of expenditures, and for the companies with direct costing system. Calculation of profitability indexes of bio assets is based upon fair value. Suggested indexes gross profit bio, operational profit bio should be calculated with regard to dynamics per unit of bio assets, per 1 ha etc. Obtained results allow judging the results of influence of managerial decisions on harvested products from bio assets.

Acknowledgments: This paper was supported by the Internal grant agency (IGA) of the Faculty of Economics and Management, Czech University of Life Sciences Prague, grant no. 2019B0011 «Economic analysis of water balance of the current agricultural commodities production mix in the Czech Republic" (Ekonomická analýza vodní bilance stávajícího produkčního mixu zemědělských komodit v ČR).

\section{References}

Alborov R. A., and Kontsevaya S. M. 2012. The development of methods for assessing and accounting for biological assets in accordance with the requirements of IAS 41 "Agriculture" (Развитие методики оценки и учета биологических активов в соответствии с требованиями МСФО 41 "Сельское хозяйство"). International accounting (Международный бухгалтерский учет): 2(200), 2-12.

Hinke Jana, and Stárová Marta. 2014. The Fair Value Model for the Measurement of Biological Assets and Agricultural Produce in the Czech Republic. Procedia Economics and Finance: 12, $213-220$. https://doi.org/10.1016/S2212-5671(14)00338-4.

Kontevoy G. 2015. Improving the methodology for assessing and recording material and biological costs in agriculture (Совершенствование методики оценки и учета материальных и биологических затрат в сельском хозяйстве). Economy of agricultural and processing enterprises (Экономика сельскохозяйственных и перерабатьвающих предприятий): 1, 26-29.

Law assistance system "Consultant plus". 2018. IFRS 41 "Agriculture" Available online: http://www.consultant.ru/document/cons_doc_LAW_193593/, (accessed on 1 December 2019).

Marcolini S., Veron CS., Goytia M., Mancini C., and Radi D. 2015. Cost accounting recognition of biological assets: the plant peach's case. Saberes: 7, 45-67.

Mikuska R., Stroparo Telma Regina, Ribeiro Flávio, and Klosowski Macohon A. L. 2017. Adoption of the Fair Value in the disclosure of biological assets: a case study in the production of Yerba Mate. Custos $e$ Agronegocio on Line: 13(4), 239-256.

Ostaev Y. Gamlet, Kondratyev V. Dmitry, Kotlyachkov V. Oleg, Konina A. Elena, Suetin N. Sergey, and Istomina A. Larisa. 2019. Improving the Methods and Approaches of Analysis and Management Accounting in Agriculture. Amazonia Investiga: 8(20), 135-143.

Rocha da S.A., Oliveira D. Deyvison, Loose C.E., and Porto S. Wellington. 2016. Measurement and disclosure of the bearer biological asset at the fair value in beekeeping: an alternative to the historical cost. Custos $e$ Agronegocio on Line: 12(3), 273-302.

Xie B.S., Wang G.H., and Wang S.H. 2019. Does biological assets affect the firms' cost of debt capital? Evidence from Chinese listed agriculture firms. Custos e Agronegocio on Line: 15(2), 22-47. 